\title{
Characterization and Optimization of Lipase Production from Soil Microorganism (Serratia marcescens)
}

\author{
E. Nwachukwu' ${ }^{1}$, E.N. Ejike ${ }^{3 *}$, B.U. Ejike ${ }^{2}$, E.O. Onyeanula ${ }^{1}$, R.O. Chikezie-Abba ${ }^{1}$, \\ N.A. Okorocha ${ }^{4}$ and U.E. Onukaogu ${ }^{3}$ \\ ${ }^{1}$ Department of Microbiology, ${ }^{2}$ Department of Zoology and Environmental Biology, Michael \\ Okpara University of Agriculture, Umudike, Abia State, Nigeria \\ ${ }^{3}$ Department of Biology/Microbiology Abia State Polytechnic, Aba Abia State Nigeria \\ ${ }^{4}$ Abia State Teaching Hospital, Aba, Abia State Nigeria \\ *Corresponding author
}

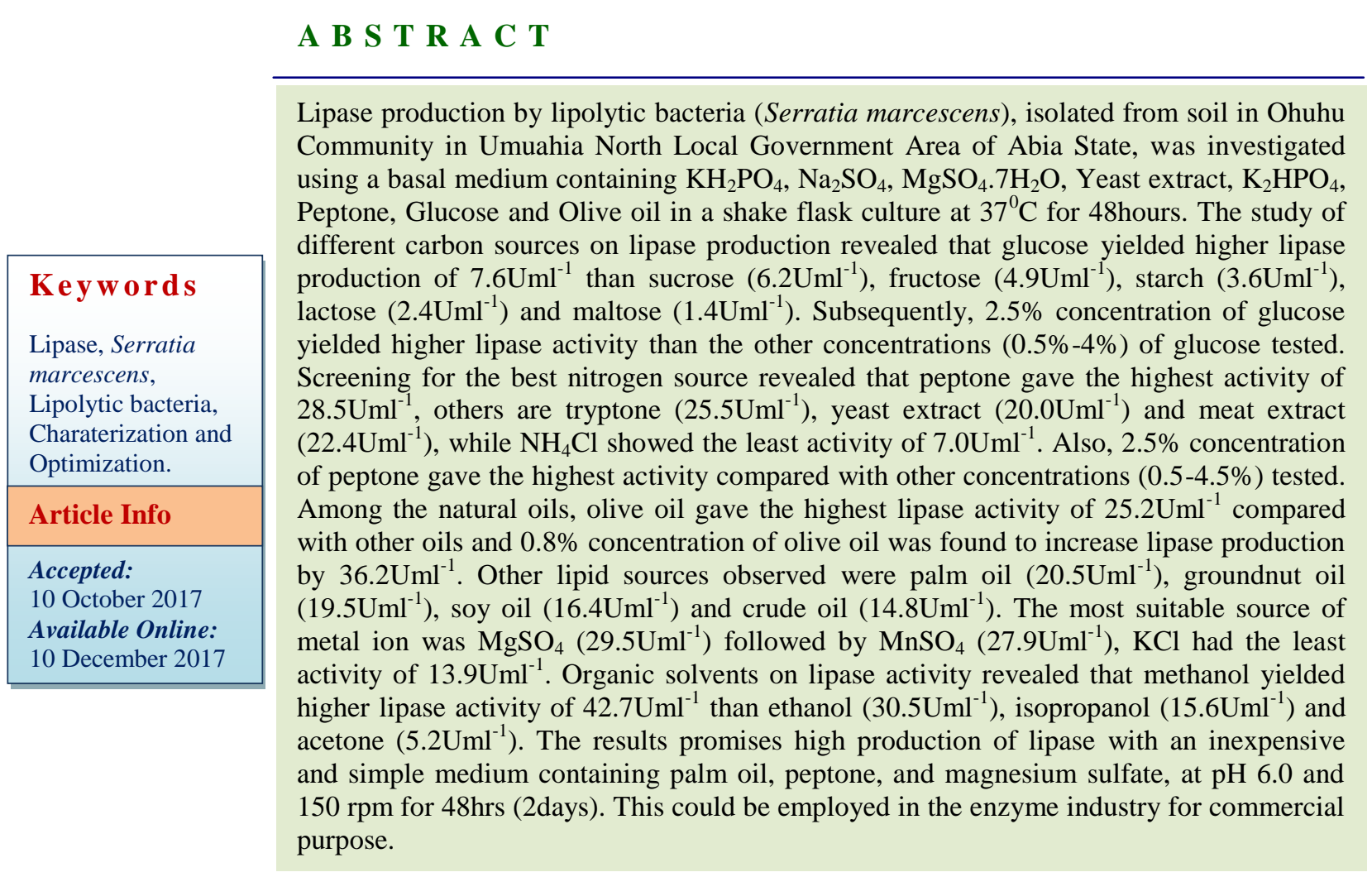

\section{Introduction}

Lipases are defined as glycerol ester hydrolases (EC3.1.1.3) hydrolyzing tri-, diand mono-glycerides present at oil-water interface (Saxena et al., 1999). Some lipases are also able to catalyze esterification, transesterification and enantioselective hydrolysis reactions (Nini et al., 2001; Shintre et al., 2002; Nagayama et al., 2002; Piao et al., 
2003; Kui et al., 2003; Raku et al., 2003). The interest in microbial lipase production has increased in the last decades, because of its large potential in a wide range of industrial applications as additives in food processing (flavor modification), fine chemicals (synthesis of esters), detergents (hydrolysis of fats), waste water treatment (decomposition and removal of oil substances), diagnostics, cosmetics (removal of lipids), pharmaceuticals (digestion of oil and fats in foods), leather (removal of lipids from animal skins) and medical (blood triglyceride assay) (Cardenas et al., 2001; Elibol and Ozer, 2000).

Lipases are produced by many microorganisms and higher eukaryotes. Enzyme-producing microorganisms include bacteria (Kulkarni and Gadre, 2002), fungi (Fodiloglu and Erkmen, 1999), yeast (Corzo and Revah, 1999) and actinomycetes (Sommer et al., 1997).

Lipases from microorganisms have drawn much attention for their potential use in biotechnology, mainly due to their availability and stability (Ghosh et al., 1996). Lipaseproducing bacteria have been found in diverse habitats such as soil contaminated with oil, dairies, industrial wastes, oilseeds and decaying food, compost heaps, coal tips and hot springs (Wang et al., 1995).

A large number of beneficial thermophiles which produced lipases with good thermal stabilities have been found in diverse habitats (Wang et al., 1995). Their thermal stabilities, particularly in the absence of appreciable amounts of water, increase their attractiveness industrially. Thermostable lipases have a lot of applications in the processing of food, domestic, industrial wastes, cosmetic, detergents and pharmaceutical industries (Saxena et al., 1999)
Hence, this present work is centered on the isolation, characterization of lipase from lipase producing bacteria and the optimization of culture conditions required for maximum enzyme production by the isolate.

\section{Materials and Methods}

\section{Sample collection}

Soil sample was collected from $4-5 \mathrm{~cm}$ depth from a palm oil processing environment located in Ohuhu Community in Umuahia North local Government Area of Abia State, Nigeria with sterile spatula in a sterile plastic bag and was transported to Microbiology Laboratory of Abia State Polytechnic, Aba.

\section{Pre-enrichment}

One gram of the soil sample was dissolved in $10 \mathrm{ml}$ sterile normal saline. After shaking, $5 \mathrm{ml}$ of the suspension was transferred into a $25 \mathrm{ml}$ enrichment medium with the following composition: $1 \%$ olive oil, $10 \mathrm{~g} / \mathrm{l}$ peptone, $3 \mathrm{~g} / \mathrm{l}$ beef extract and $5 \mathrm{~g} / \mathrm{l} \mathrm{NaCl}$ at $\mathrm{pH} 7.0$ (Pallavi et al., 2010). The culture was incubated at $30^{\circ} \mathrm{C}$ for 24 hours. $1 \mathrm{ml}$ of the enriched culture suspension was serially diluted up to $10^{-7}$ dilutions and plated onto nutrient agar plates. Discrete colonies were picked and purified by sub-culturing onto NA, until their pure cultures were obtained and subjected to screening for extra cellular lipase production.

\section{Lipase Assay}

Lipase activity was determined by measuring the release of fatty acids from olive oil emulsion as described by Adinarayana et al., (2004) using the titrimetric method. $0.2 \mathrm{ml}$ of the enzyme substrate mixture was incubated at $37^{\circ} \mathrm{C}$ for $30 \mathrm{~min}$. The reaction was terminated by adding $2 \mathrm{ml}$ acetone-ethanol mixture $(1: 1 \mathrm{v} / \mathrm{v})$. The amount of fatty acid liberated was determined by titration with 
$0.01 \mathrm{~N} \mathrm{NaOH}$ using phenolphthalein as indicator. All experiments were run in triplicate sets and the mean values were presented. The values were analyzed using analysis of variance (ANOVA).

\section{Effect of carbon sources on lipase activity}

The effect of various carbon sources such as maltose, fructose, glucose, sucrose, lactose and starch on enzyme activity was determined by adding the carbon sources to the basal medium at $1 \%(\mathrm{w} / \mathrm{v})$ as described by Gryzna et al., (2007).

\section{Effect of concentration of glucose on lipase activity}

The effect of varying concentrations of the best carbon source (glucose) in the fermentation medium for the production of lipase was evaluated. $5 \mathrm{mls}$ of the broth culture was inoculated into $250 \mathrm{ml}$ conical flasks each containing $100 \mathrm{ml}$ sterile basal medium with ranging concentration (0.1-4.5\% w/v) glucose.

Fermentation was carried out in an orbital shaker at $150 \mathrm{rpm}$ for $72 \mathrm{hrs}$ at $50^{\circ} \mathrm{C}$ thereafter, centrifuged. The cell free filtrate was used to assay for lipase activity as earlier described.

\section{Effect of natural oil as additive on lipase activity}

The effects of $1 \% \mathrm{v} / \mathrm{v}$ of various oils on lipase production were investigated by replacing olive oil used in the basal medium for preliminary study with; crude oil, palm oil, soy oil and groundnut oil as described by Pallavi et al., (2010).

\section{Effect of concentration of olive oil on lipase activity}

The effect of concentration $(0.1-3.5 \% \mathrm{v} / \mathrm{v})$ of the best natural oil source (olive oil) on lipase production was evaluated. Five milliliters of the broth culture were inoculated into $250 \mathrm{ml}$ conical flasks each containing $100 \mathrm{ml}$ sterile production medium with ranging concentration $(0.1-3.5 \% \mathrm{v} / \mathrm{v})$ crude oil as described by Pallavi et al., (2010).

\section{Effect of nitrogen substrates on lipase activity}

The following nitrogen substrates $(2 \% \mathrm{w} / \mathrm{v})$ were used to evaluate the influence of organic and inorganic nitrogen sources on lipase production by the bacteria; yeast extract, soy meal, peptone, groundnut meal, tryptone, meat extract, ammonium chloride $\left(\mathrm{NH}_{4} \mathrm{Cl}\right)$ and potassium nitrate $\left(\mathrm{KNO}_{3}\right)$.

Each of the nitrogen sources was used as a sole source of nitrogen in place of yeast extract and peptone employed in the basal medium. Fermentation was carried out in an orbital shaking incubator at 130rpm for 48hrs at $37^{\circ} \mathrm{C}$ and cell free filtrate was obtained as had been described.

\section{Effect of concentration of peptone on lipase activity}

The effect of varying concentrations of the best Nitrogen source (peptone) in the fermentation medium for the production of lipase was evaluated. $5 \mathrm{ml}$ of the broth culture was inoculated into $250 \mathrm{ml}$ conical flasks each containing $100 \mathrm{ml}$ sterile basal medium with ranging concentration $(0.1-4.5 \% \quad \mathrm{w} / \mathrm{v})$ peptone. Fermentation was carried out in an orbital shaker at $150 \mathrm{rpm}$ for $72 \mathrm{hrs}$ at $50^{\circ} \mathrm{C}$ thereafter, centrifuged. The cell free filtrate was used to assay for lipase activity as earlier described.

\section{Effect of metal ions on lipase activity}

The effect of different metal ions on lipase production was determined by pre-incubation of $1 \mathrm{ml}$ of the crude enzyme extract with $1.5 \%$ 
concentration of the various salts of metals; $\mathrm{FeSO}_{4}, \mathrm{MgSO}_{4}, \mathrm{NaCl}, \mathrm{CaCl}_{2}, \mathrm{ZnSO}_{4}, \mathrm{KCL}$ and $\mathrm{MnSO}_{4}$ ) at $37^{\circ} \mathrm{C}$ for 1 hour as described by Anjana et al., (2009).

\section{Effect of concentration of mgso $_{4}$ on lipase production}

The effect of varying concentrations of the best metal ion $\left(\mathrm{MgSO}_{4}\right)$ was evaluated. Different concentration $(0.5-3.5 \% \mathrm{w} / \mathrm{v})$ was inoculated into $250 \mathrm{ml}$ conical flasks containing $1 \mathrm{ml}$ of the crude enzyme extract. Fermentation was carried out in an orbital shaker at $150 \mathrm{rpm}$ for $72 \mathrm{hrs}$ at $50^{\circ} \mathrm{C}$.The residual activity was determined under the standard assay conditions.

\section{Effect of pH on lipase activity}

The effect of $\mathrm{pH}$ on the enzymatic activity of the lipase fraction was determined using a wide range of buffers, including $1 \mathrm{M}$ citrate phosphate $(\mathrm{pH}$ 3.0-7.0), 1M sodium phosphate (6.0-7.0), 1M Tris-HCL (pH 8.0) and $1 \mathrm{M}$ glycine- $\mathrm{NaOH} \quad(\mathrm{pH}$ 9-10) as described by Anjana et al., (2009). One millilitre of the crude enzyme extract was incubated for 1 hour at $37^{\circ} \mathrm{C}$ with respective buffers mentioned. The $\mathrm{pH}$ values were checked using a digital $\mathrm{pH}$ meter. The residual enzyme activity was estimated under standard assay conditions after the fermentation.

\section{Effect of temperature on lipase activity}

The effect of temperature on lipase activity was determined by assaying the enzyme activity at different temperatures ranging from $30^{\circ} \mathrm{C}-80^{\circ} \mathrm{C}$ at $\mathrm{pH} 9$, as described by Anjana et al., (2009). The thermostability was monitored by incubating $1 \mathrm{ml}$ of the crude enzyme extract at respective temperatures for $1 \mathrm{hr}$ and then enzyme activity measured under standard assay conditions.

\section{Effect of organic solvents on lipase activity}

The effect of different organic solvents on lipase production was determined by preincubation of $1 \mathrm{ml}$ of the crude enzyme extract with $1.5 \%$ concentration of the various solvents (acetone, isopropanol, ethanol and methanol) at $37^{\circ} \mathrm{C}$ for 1 hour as described by Anjana et al., (2009). The residual activity was determined after the fermentation.

\section{Results and Discussion}

Lipases are a group of enzymes, present in microoganisms, plants and animals, which have the ability to hydrolyse triacylglycerol at an oil-water interface to release free fatty acids and glycerol. Their biotechnological potential is relying on their ability to catalyze not only the hydrolysis of a given triacylglyceride, but also its synthesis from glycerol and fatty acids. However, the aim of this study was the isolation of lipolytic bacteria from the local soil sample.

Carbon source is an important substance for energy production in microorganisms especially in bacteria (Pogaku et al., 2009). A range of different carbon sources has been reported to support both growth and lipase production (Dharmendra et al., 2010). Carbon sources that were investigated showed the ability to stimulate lipase production. However, glucose showed the highest value for lipase stimulation (Fig. 1). The lipase yield was maximum at $2.5 \%$ concentration with activity of $19.2 \mathrm{U} / \mathrm{ml}$. The carbon concentrations at $1 \%$ and $2 \%$ results to the slight decline in lipase production to $15.0 \mathrm{U} / \mathrm{ml}$ and $17.2 \mathrm{U} / \mathrm{ml}$ respectively (Fig. 2). The decrease in the productivity at higher concentration could be due to the viscosity of the medium component. The influence of different carbon sources on the production of lipase was found to be statistically significant $(\mathrm{p}<0.05)$ by the one-way ANOVA 
All the natural oils; Groundnut oil, Crude oil, Soy oil, palm oil and Olive oil were shown to induce lipase production at varying degrees (Fig. 7). Various oils are reported to constitute different types of fatty acids some of which lipase have much higher affinity for than others. Interestingly this bacterium was able to produce similar high lipase activity with all studied oils. This is quite important since it means that the cheapest and most available oil could be used as a convenient carbon source for industrial scale production. This is in compliance with the report by Sirisha et al., (2010). Among these, olive oil was found to be successful with respect to lipase production by Serratia sp. Olive oil was also previously reported as the best substrate for lipase production with Bacillus sp. strain 42 (Eltaweel et al., 2005). The above finding was similar to that by Becker et al., (1997) who found that olive oil was the best inducer of lipase production by the Bacillus sp.

This is also in agreement with the report by Sirisha et al., (2010), Vishnupriya et al., (2010), and Essakiraj et al., (2010), who showed the ability of olive oil as best carbon source in lipase production when compared with other oils. Palm oil was selected as a potential substrate for the industrial production of lipase over olive oil based on economic reasons of availability and cost of purchase because olive oil is much more expensive and not readily available and this in turn could eventually affect the cost of production of lipase enzyme. One-way ANOVA showed that the influence of various lipid sources on total lipase production was statistically significant $(\mathrm{p}<0.05)$.

Nitrogen sources play important role in the biosynthesis of lipase by microorganisms. Yeast extract, soy meal, peptone, ammonium chloride, malt extract, groundnut meal, potassium nitrate were investigated. Results obtained on the effect of nitrogen sources shows the various effect of nitrogen sources with peptone as sole carbon source (Fig. 3 and 4). Peptone was preferred by the isolate for the production of lipase as a nitrogen source as it showed significant lipase activity of 28.5Uml. The study by Breuil et al., (1997) revealed peptone as the best source of nitrogen in Cellotrichum glosporoides using pongamia oil cake. Szatajer et al., (1988) and Szatajer et al.,(1989) have also reported peptone as the best source of nitrogen for lipase production Different concentration of peptone showed constant increment in activity and the highest was at $2.5 \%$, then sudden decline at $3 \%$ concentration.

Ammonium chloride showed the least ability of the organism to produce lipase in huge amounts, this is in contrast with the work by Pogaku et al., (2009) who reported the ability of Ammonium chloride to stimulate lipase activity when used for lipase production by Staphylococcus Sp LP 12.

The results obtained showed that ammonium chloride slightly stimulated lipase production when compared with other nitrogen sources. Malt extract showed the ability to stimulate lipase synthesis but showed highest increase when crude oil was used as a sole carbon source. Sekhon et al.,(2006) has reported on the use of malt extract as a source of nitrogen for lipase production. There exist reports on the use of soy meal as a source of nitrogen but more reported that it was found not to be the best source with any organism (Essakkiraj et al., 2010; Vargas et al., 2008; Kempka et al., 2008). This could mean that soymeal contain certain cations which repress or inhibit lipase activity and can only be employed when these cations had been removed by an ionexchanger; which when considered from the economic standpoint may not be ideal or good for lipase production or may be costintensive. 
Therefore soybean may have the tendency to stimulate lipase production, but cannot be employed in the industrial scale production of the enzyme. Reports have shown that yeast extract can be dependable for large scale production of lipase enzyme (Dheeman et al.,
2010). Yeast extract stimulated lipase production in the present study but was not generally found to be the best source This is in contrast with the observation of Dheeman et al., (2010); who reported the ability of yeast to stimulate maximum activity.

Plate.1 Showing orange fluorescence colonies of isolate on Rhodamine B Agar under UV irradiation

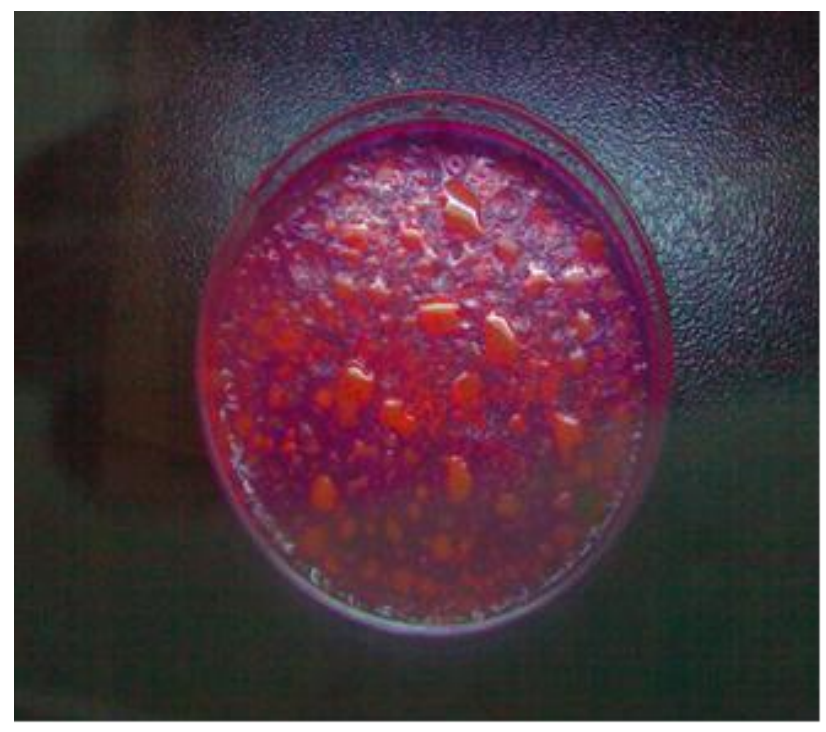

Plate.2 Showing no visible orange fluorescence colonies under UV irradiation

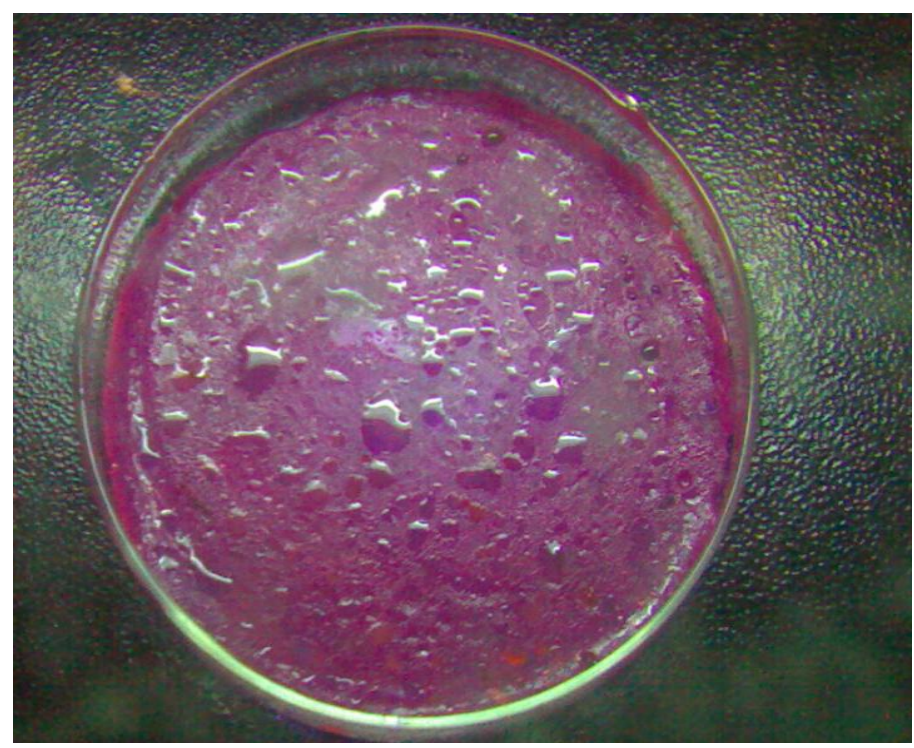


Fig.1 Effect of carbon sources on lipase activity

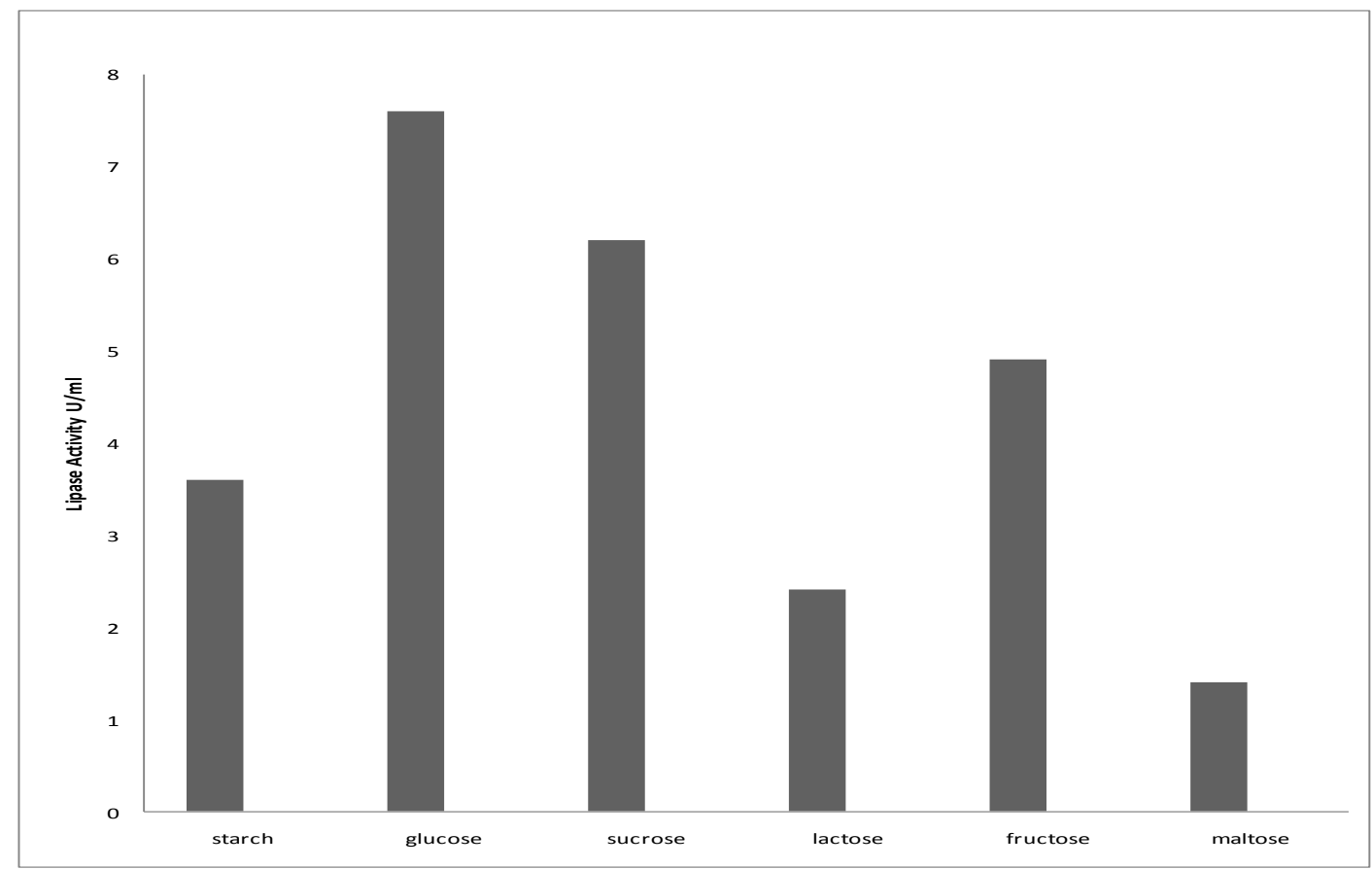

Fig.2 Effect of concentrations of carbon source (glucose) on lipase production by Serratia marsecens

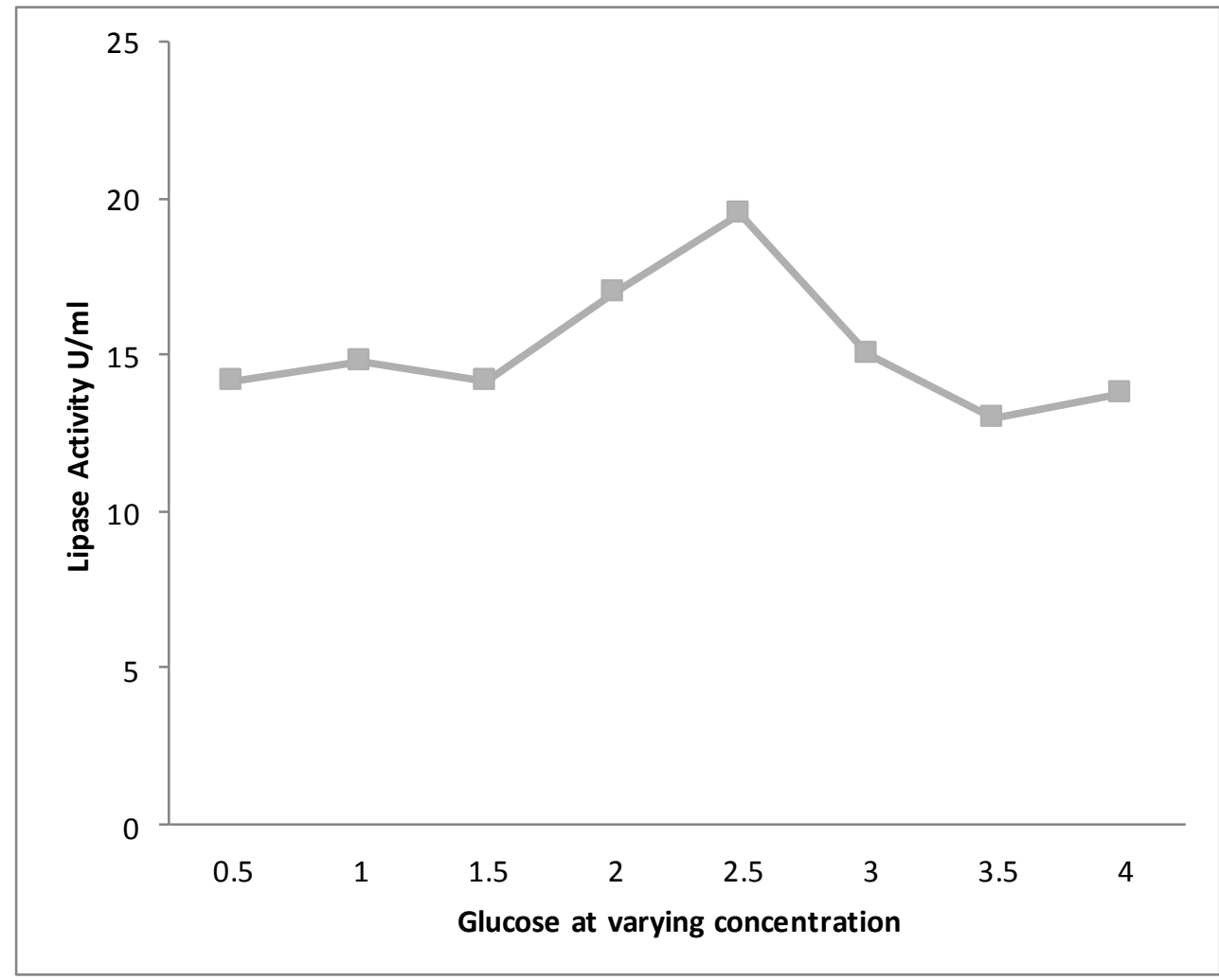


Fig.3 Effect of nitrogen sources on lipase activity

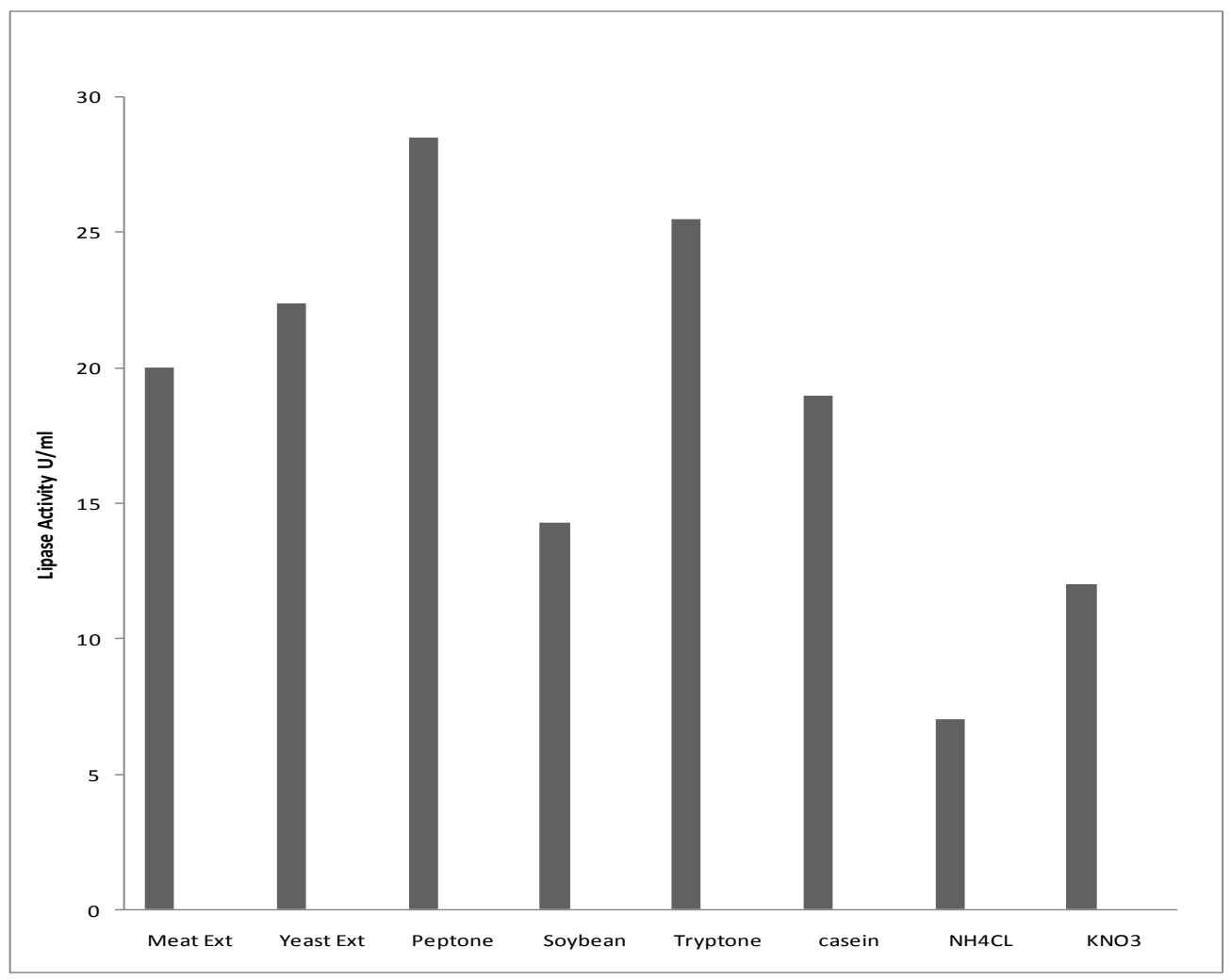

Fig.4 Effect of concentration of nitrogen source (peptone) on lipase production by Serratia marsecens

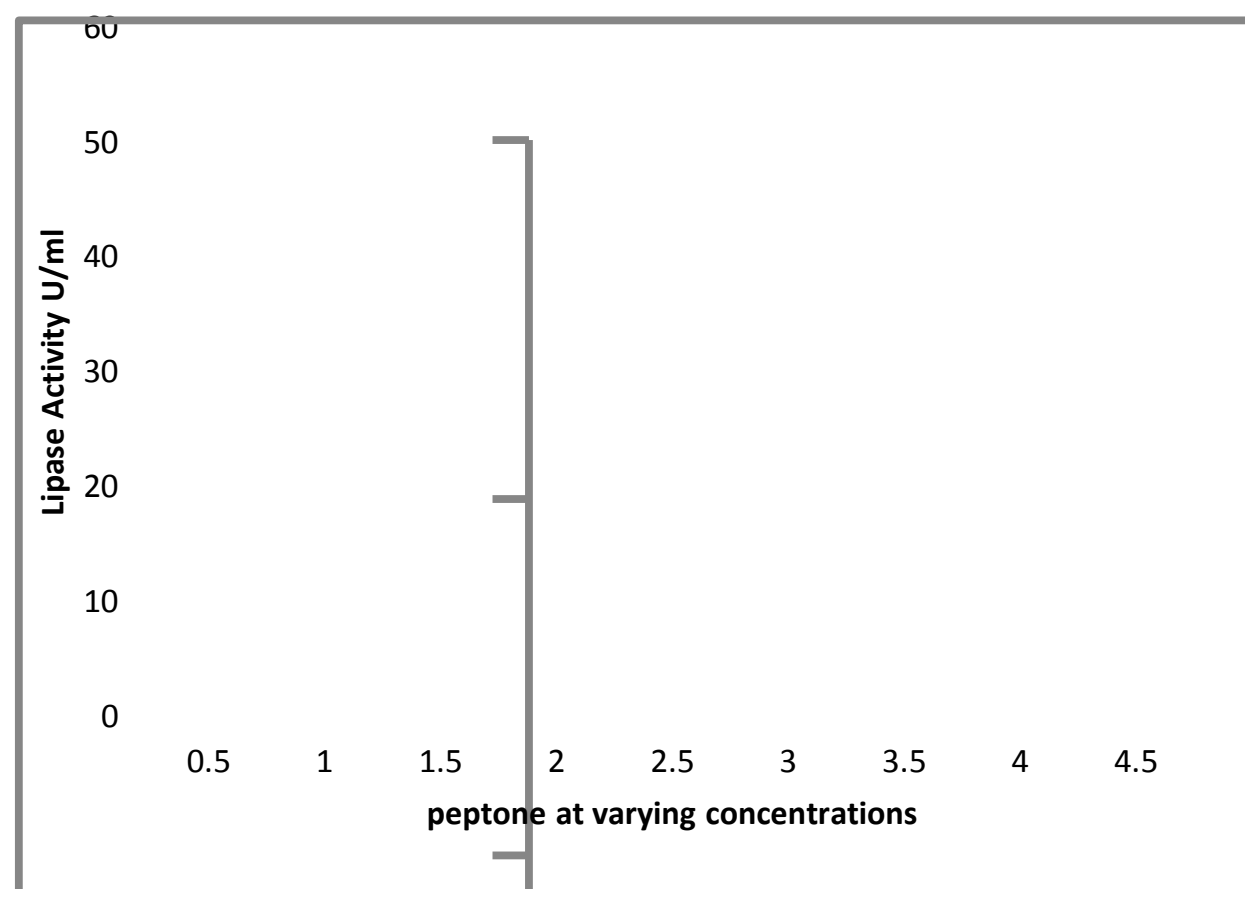


Fig.5 Effect of metal ions on lipase activity

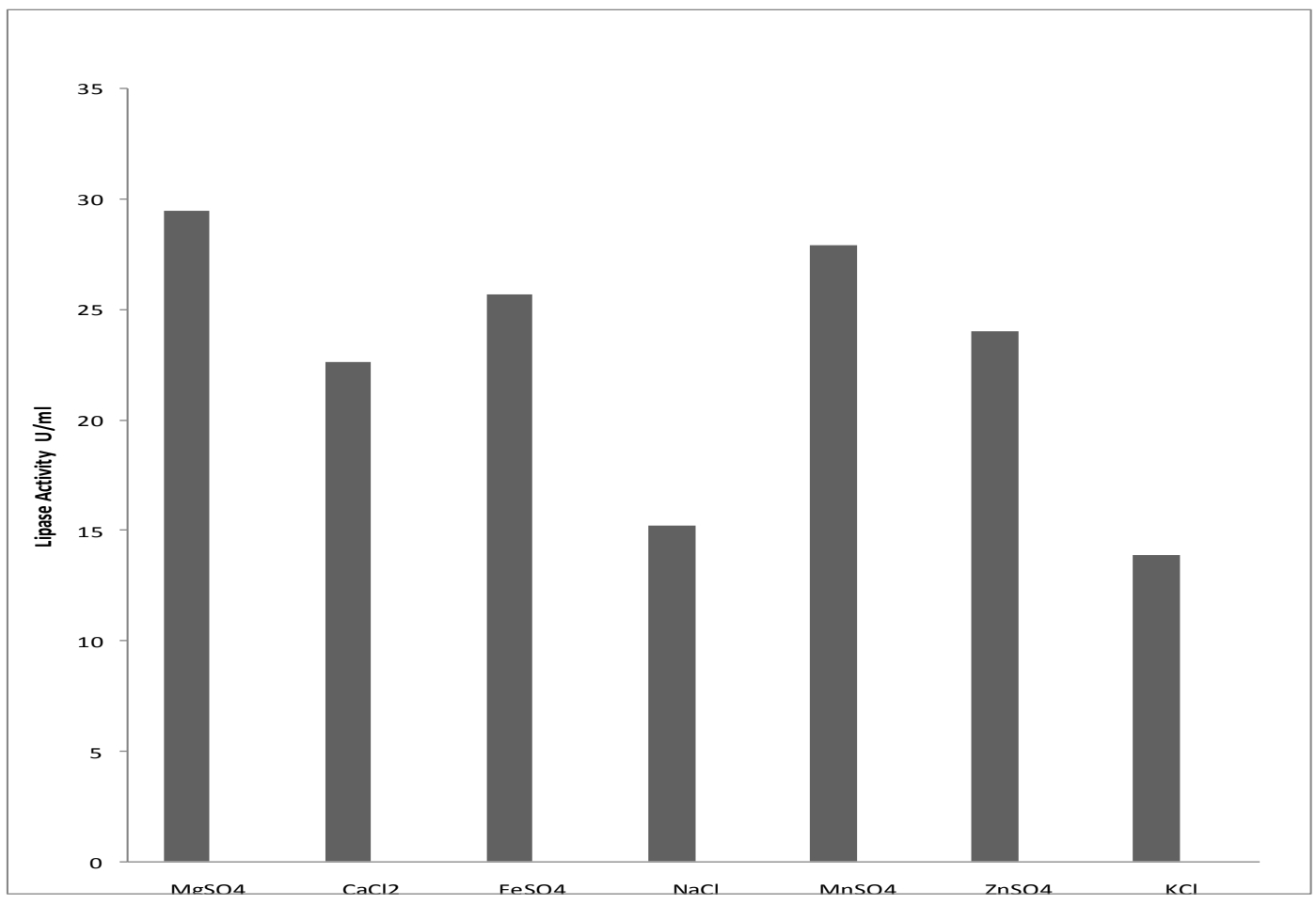

Fig.6 Effect of metal ion concentrations $\left(\mathrm{MgSO}_{4}\right)$ on lipase production

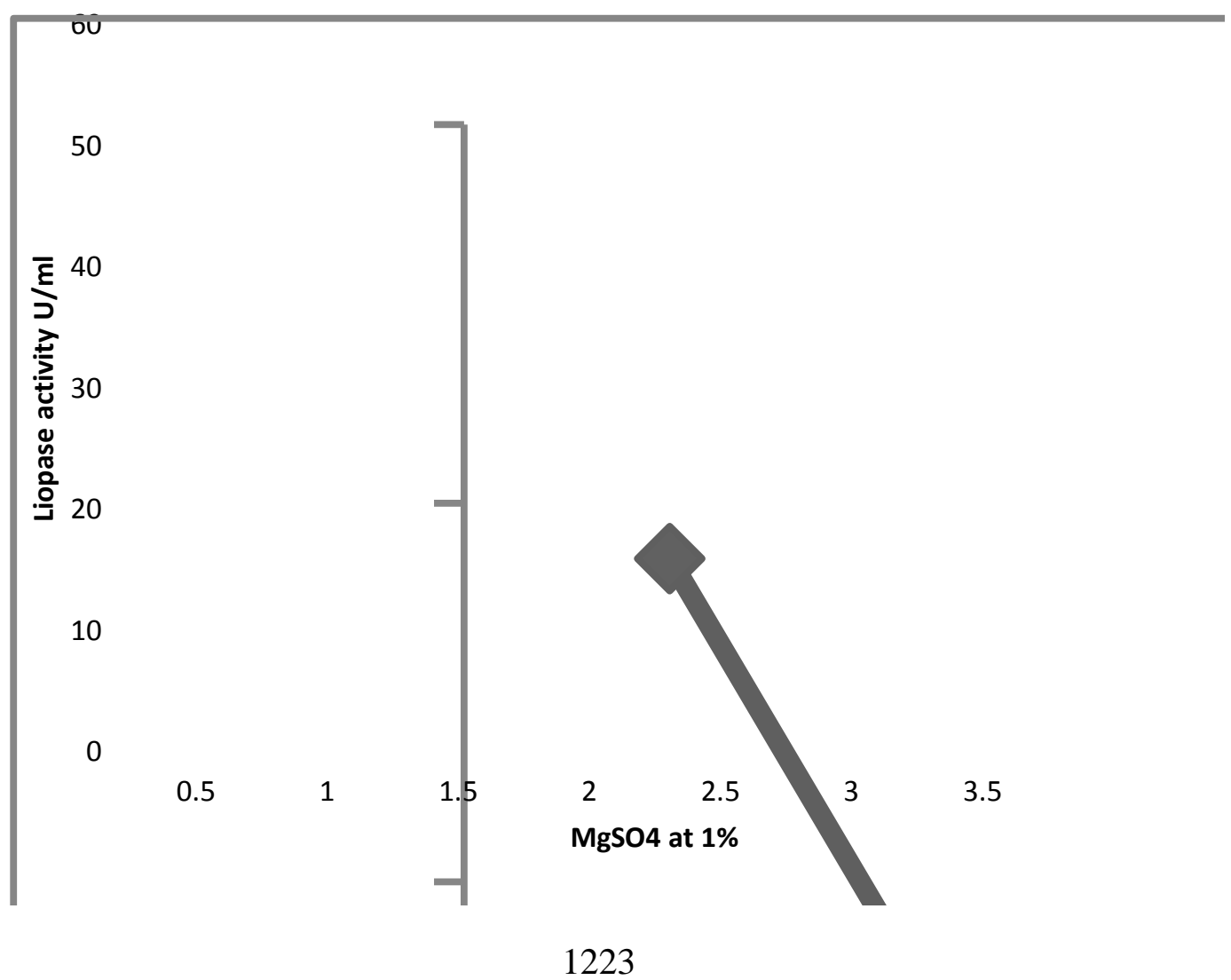


Fig.7 Effect of natural oil on lipase activity

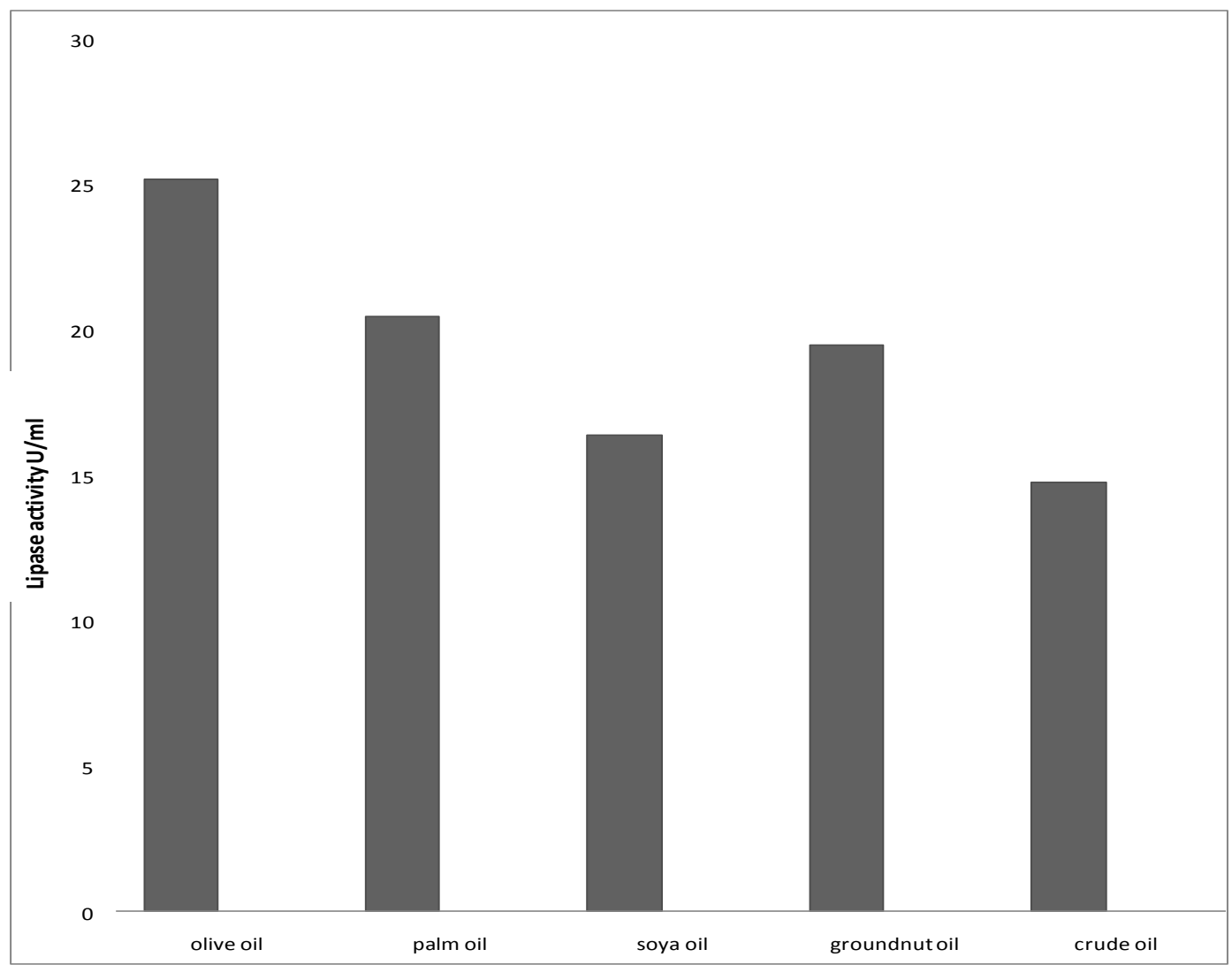

Fig.8 Effect of olive oil concentrations on lipase production by Serratia marsecens

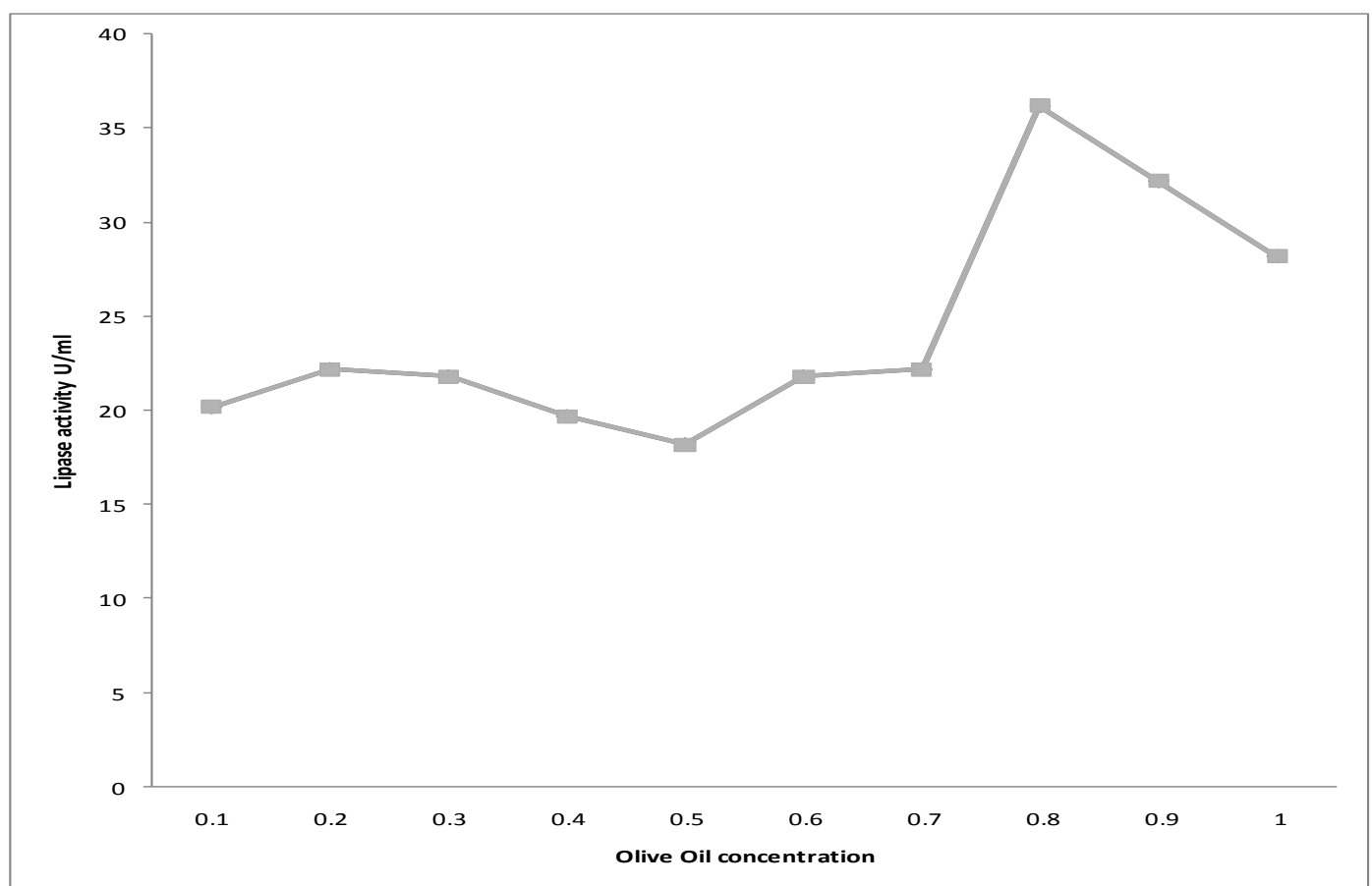


Int.J.Curr.Microbiol.App.Sci (2017) 6(12): 1215-1231

Fig.9 Effect of agitation rates on lipase activity

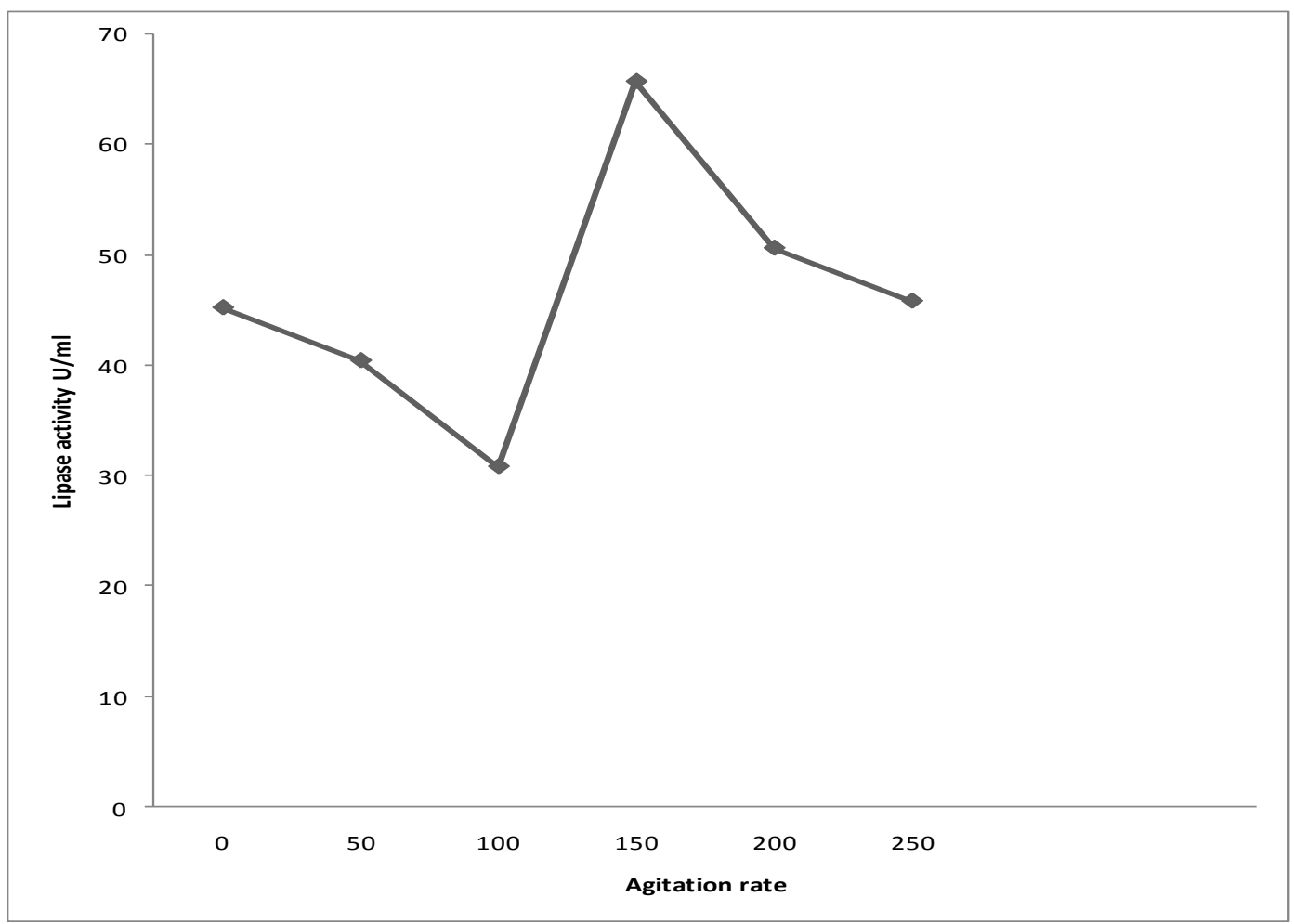

Fig.10 Effect of temperature ranges on lipase activity

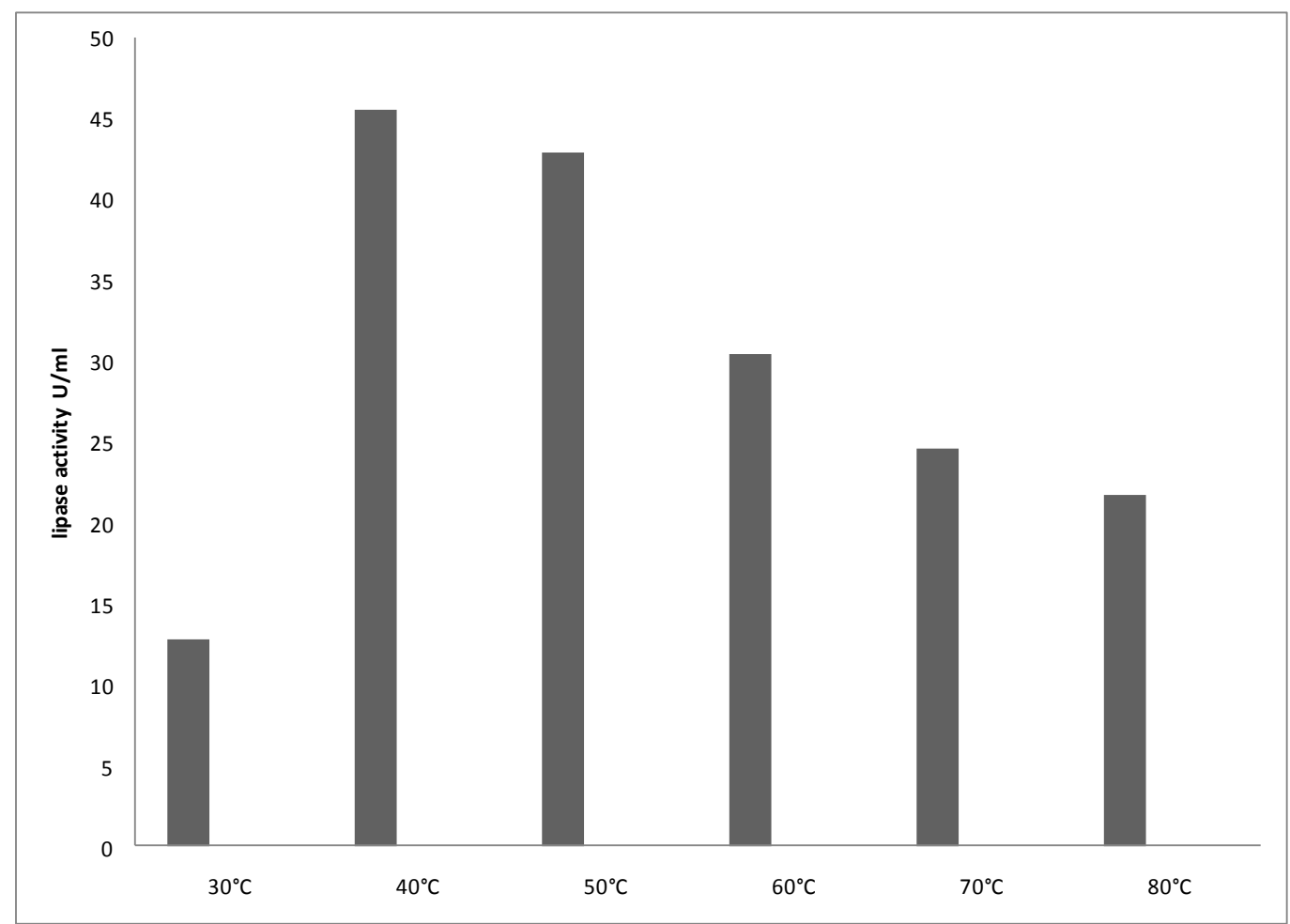


Int.J.Curr.Microbiol.App.Sci (2017) 6(12): 1215-1231

Fig.11 Effect of $\mathrm{pH}$ on lipase activity

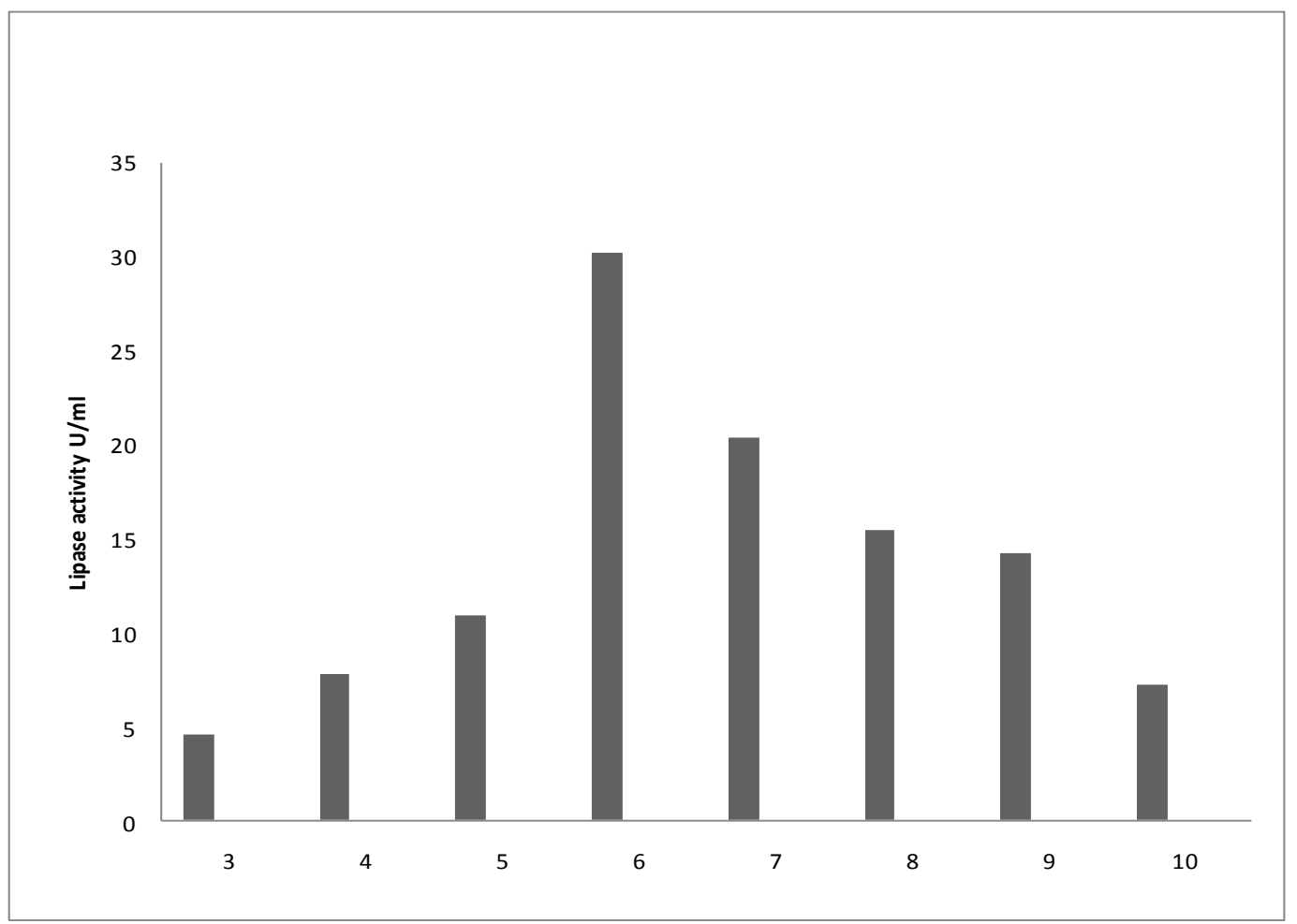

Fig.12 Effect of organic solvents on lipase activity

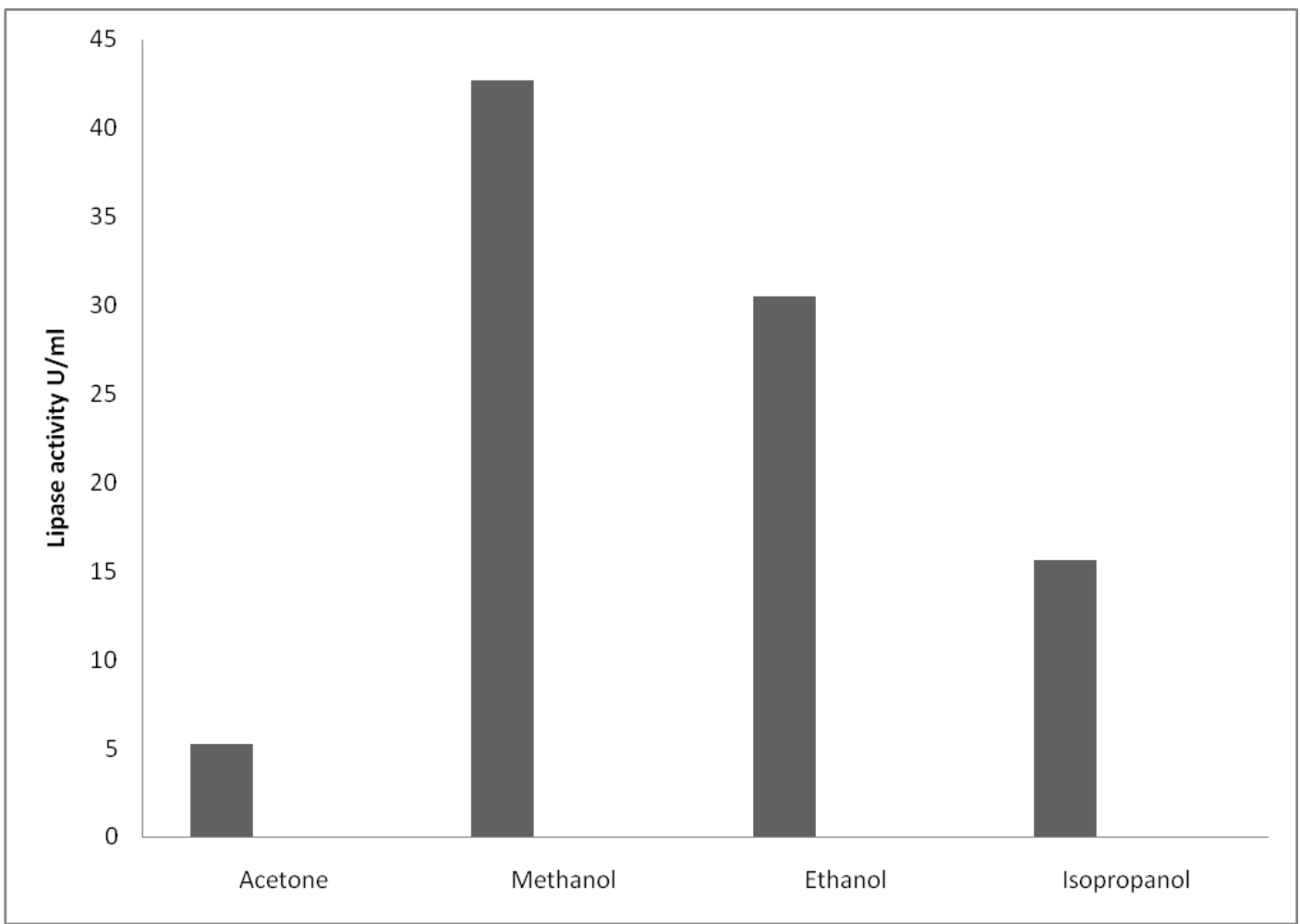


Fig.13 Effect of different concentrations of methanol on lipase production

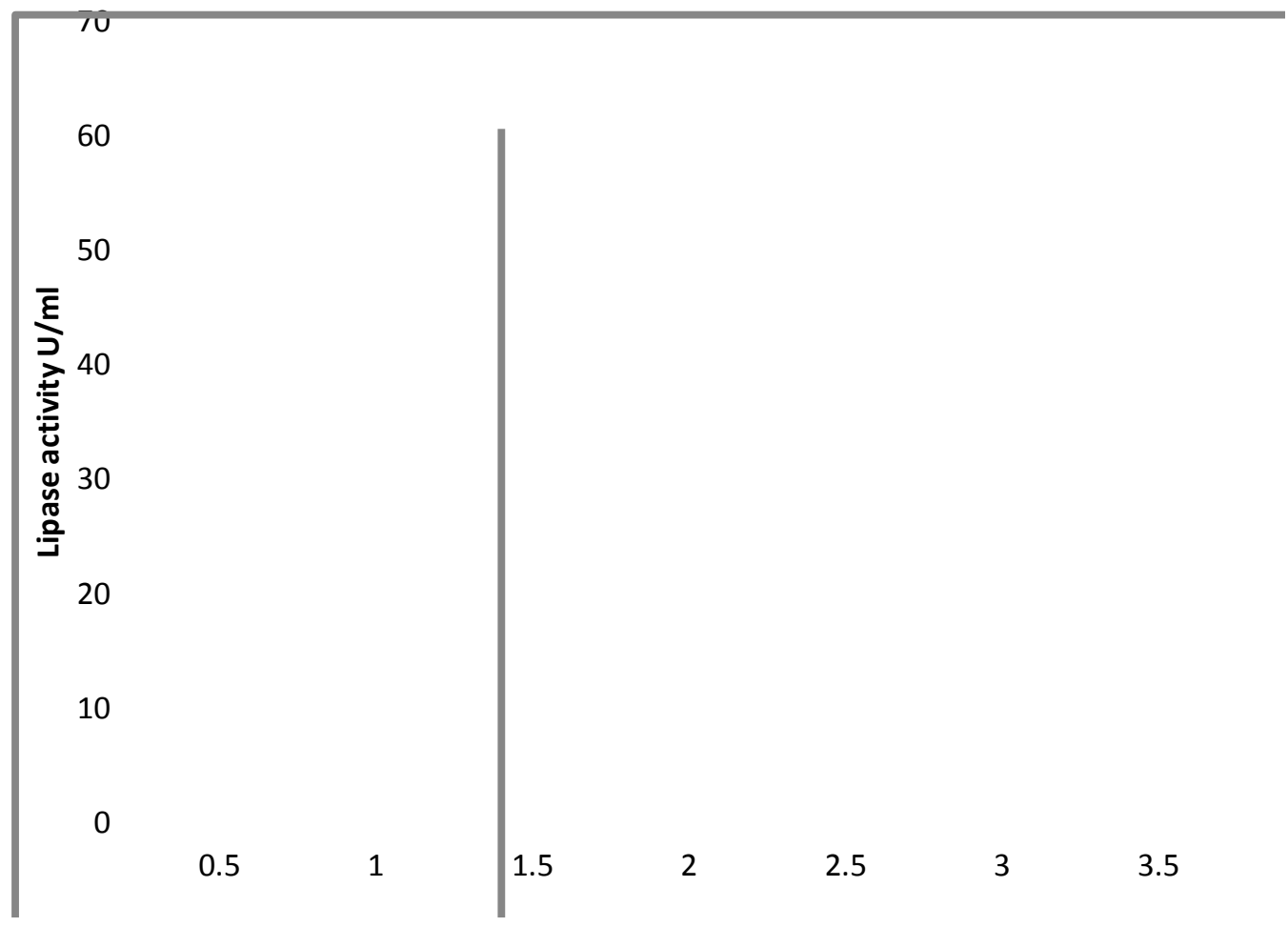

Fig.14 Effect of incubation time (hours) on lipase activity

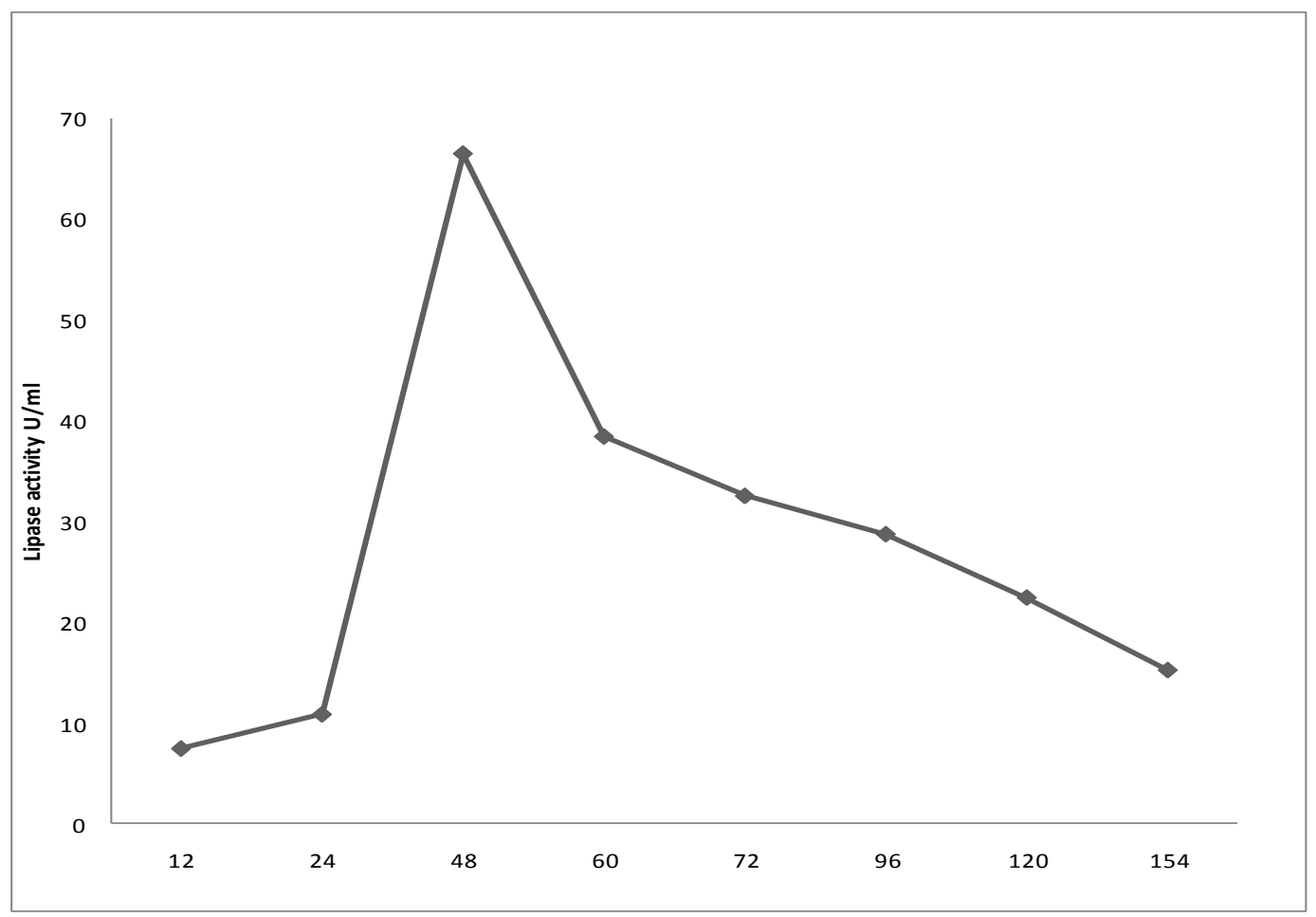


Considering the effects of the various treatments involving nitrogen sources, the results showed that organic sources of nitrogen is a very important component for the growth of organism as appreciable growth values were observed with organic sources but not with inorganic sources. This could be because inorganic nitrogen sources are used up quickly, while organic nitrogen source can supply cell growth factors and amino acids needed for cell metabolism and enzyme synthesis.

Nitrogen sources are highly important for both growth of the bacterium and lipase production. Their tendency to stimulate lipase production more than carbon sources, make them the most important nutrient for the maximum production of lipase. The statistical analysis by one-way ANOVA showed that the influence of nitrogen sources on total lipase production was statistically significant $(\mathrm{p}<$ 0.05). An increase in lipase activity (synthesis and hydrolysis) after incubation in organic solvents (Fig. 12 and 13) showed that methanol and ethanol gave the highest lipase production of $42.7 \mathrm{U} / \mathrm{ml}$ and $30.5 \mathrm{U} / \mathrm{ml}$ respectively while Isopropanol gave an activity $15.6 \mathrm{U} / \mathrm{ml}$. Acetone gave the least activity of $5.2 \mathrm{U} / \mathrm{ml}$. As suggested by Chen and $\mathrm{Wu}$ (2003), the increase in enzymatic activity could be explained by the structural transition from the inactive "closed" form of lipase to the active "open" form, as a result of the treatment with organic solvents. Methanol is widely used as the acyl acceptor and is often favoured over other alcohols because of its low cost.

All the trace elements employed in the original medium used in the initial production were substituted with various salts of both macro elements and micro elements alone without any other salt. Trace elements such as $\mathrm{Fe}^{2+}$ and $\mathrm{Mn}^{2+}$ among others are found in almost all the media used for lipase production. These salts include ferrous sulphate, maganesse sulphate, magnesium sulphate, sodium chloride, potassium chloride, calcium chloride and zinc sulphate were all employed.

Potassium chloride and sodium chloride found to yield almost equal synthesis of lipase production were also found to be the least among the rest in its ability to stimulate lipase production. This shows that potassium ions along side with sodium are not good lipase stimulators. The ability of the rest of the salts to stimulate lipase production is not new; manganese and ferrous sulfate had been shown by to have stimulated lipase production. Dheeman et al., (2010) has reported the use of $\mathrm{Mn}^{2+}, \mathrm{Fe}^{2+}, \mathrm{Mg}^{2+}$ and $\mathrm{NH}^{4+}$ to enhance lipase production. Increase lipase production was observed when Magnesium sulphate was used followed by manganesse sulfate (Fig. 5 and 6). This is in agreement with the work of Jagtap et al., (2010) who reported that the best source of metal ion was found to be magnessium sulphate, followed by ferrous sulphate. Increased lipase activity has been found to increase when combinations of glucose and magnessium salts are employed as carbon source and metallic salts respectively (Jagtap et al., 2010). Concentration of $0.5 \%$ gave the maximum lipase activity and gradually decreased upon increasing concentration; this shows that the effect of magnessium sulphate required minimal concentration even though their effects at increase concentration are not negligible. Magnessium sulphate was found to give the best yield.

In the present study, lipase activity showed gradual increase in temperature from $30^{\circ} \mathrm{C}$ $40^{\circ} \mathrm{C}$ and further increase of temperature beyond $40^{\circ} \mathrm{C}$, the production decreased (Fig 10). Thus the action of protease may be responsible for the remarkable thermal stability of the crude enzyme. This may be 
ascribed to the poor stability of extracellular lipase, the release of more protease from dead cells, and higher protease reaction rate at higher temperature (Hong et al., 2002). Statistical analysis by one-way ANOVA test for the data on lipase activity as a function of medium temperature change indicated a highly significant variation $(\mathrm{p}<0.05)$. The $\mathrm{pH}$ of the medium is important for lipase production. Lipase activity and growth is affected by the $\mathrm{pH}$ of the medium. Molecular charges and consequently molecular interactions and functions are directly related to medium $\mathrm{pH}$ (Dheeman et al., 2010); thus any change in medium affects any biological functions (Moon and Parulekar, 1991). The results of lipase production at increasing $\mathrm{pH}$ showed decreasing lipase across the $\mathrm{pH}$ gradient with the highest production found at $\mathrm{pH}$ 6.0; followed by $\mathrm{pH} 7.0$ and the least at $\mathrm{pH} 3.0$ (Fig. 11). This shows that the lipase produced by this organism is an acidic lipase. The ability of organisms to produce slightly acidic lipase has been reported by Pogaku et al., (2010) and Rajesh et al., (2010). There is an indication that proteases which are known to be secreted from dead cells may be more active at $\mathrm{pH}$ greater than 7.00 according to Hong et al., (2002). One-way ANOVA test conducted to obtain the data on lipase production as a function of medium $\mathrm{pH}$ revealed a highly significant variation ( $\mathrm{p}<$ $0.05)$.

Determination of the effect of agitation of production media, were kept in static and different shaking conditions. At static conditions lipase activity was much more lower than that of subsequent 50rpm - 100rpm agitation. Optimum shaking conditions required for lipase production was found to be 150rpm (Fig. 9). At 200rpm shaking condition, lipase production was slightly decreased this maybe due to cell disruption and resulting in the release of intracellular enzymes such as protease and esterase that can digest lipase enzymes (Rajesh et al., 2010). Shaking speeds, 100 and 50rpm seemed to disrupt the microaerophilic or near aerobic conditions required for maximum lipase production. This reveals the ability of the organism to produce lipase enzyme maximally at high increase in the availability of oxygen.

\section{Acknowledgement}

Authors wish to acknowledge TETUND sponsorship in this research

\section{References}

Adinarayana, K., Bapi, R., Iqbal, Z., Bhavani, D., Jhansi, L. and Ellaiah, P. (2004). Optimization of process parameters for production of lipase in solid-state fermentation by newly isolated Aspergillus species. Journal of Biotech. 3:65-69.

Anjana, S., Dipa, B. and Rashmi, P. (2009). Optimization of Physical parameters for lipase production from Arthrobacter sp. BGCC\#490. India J. of Biochemistry and Biophysics. 46:178-183.

Becker, P., I. Abu-Reesh and A. Markossian, (1997). Determination of the kinetic parameters during continuous cultivation of the lipase-producing thermophilic Bacillus sp. IHI-91 on olive oil. Appl. Microbiol. Biotechnol. 48: 184-190.

Breuil, C., D.B. Shindler, J.S. Siyher and D.J. Kushner (1997). Stimulation of lipase production during bacterial growth on alkanes. J. Bacteriology, 133(2): 601-606

Cardenas, J., E. Alvarez, M.S. de CastroAlvarez, J.M. Sanchez-Montero, M. Valmaseda, S.W. Elson and J.V. Sinisterra (2001). Screening and Catalytic activity in organic synthesis of novel fungal and yeast lipase. J. Mol. Catal. B. Enzym., 14: 111-123.

Corzo, R. and S. Revah (1999). Production and characteristics of the lipase from Yarrowia lipolytica 681. Bioresource 
Technol. 70: 173-180

Dharmendra, S.D, M.F, Jesus and T.M.H. Garry, (2010). Influence of cultivation on the production of a thermostable extracellular lipase from Amycolatopsis meditevvanei. D.S.M 43304. Indian J. of Biotechnol., 37:1-17

Dheeman, D.S., Frias, J.M. and Henehan, G.T.M. (2010). Influence of cultivation conditions on the production of a thermostable extracellular lipase from Amycolatopsis mediterranei DSM 43304. J. Ind. Microbiol. Biotechnol., 37, 1-17

Elibol, M. and D.Ozer (2000). Influence of oxygen transfer on lipase production by Rhizopus arrhizus. Proc. Biochem. 36: 325-329.

Eltaweel, M. A., R.N.Z.R.A. Rahman, A.B. Salleh and M. Basri, (2005). An organic solvent-stable lipase from Bacillus sp. strain 42. J. Ann. Microbiol., 55(3): 187192.

Esakkiraj, P., M. Rajikunar, A. Palavesam and G. Immanuel (2010). Lipase production by Staphylococcus epidermidis CMSSTPI Isolated from the gut of Shrimp Penaeus indicus. J. Ann. Microbiol. 60: 37-42.

Fodiloglu, S. and O. Erkmen (1999). Lipase production by Rhizopus oryzae growing on different carbon and nitrogen sources. 79: 1936-1938.

Ghosh, P.K, T.K. Saxena, R. Gupta, R.P.Yadar and S. Dvidson (1996). Microbial lipases: Production and Applications. Sci Prog. 79: 119-157.

Gryzyna, G., Hee-Yeon, C.H.O., Nam-Seok, C.H.O and Shoji, O.H.G.A. (2007). Effect of Culture Conditions on Growth and Lipase Production by A Newly Isolated Strain, Geotrichum-like R59 (Basdiomycetes). J. Fac. Agr. 52(1): 2934.

Gupta, R., Rathi, P. and Bradoo, S. (2003). Lipase mediated upgradation of dietary fats and oils. Crit Rev Food Sci Nutr., 43:635-644.

Gupta, R.N. Gupta and P. Rathi (2004). Bacterial Lipases: An overview of production, purification and biochemical properties. Applied Microbiol. Biotechnol. 64(6): 763-781.

Jagtap, S., Gore, S., Yavankar, S., Pardesi, K. and Chopade B. (2010). Studies on nutritional requirements of Pseudomonas aeruginosa for lipase production. Indian J. Experimental Biol. 48: 936.

Kempka, A, N.R. Lipke, T.L.F, Pinheiro, S, Menoncin, H. Treichel and D.M.G., Freire (2008). Response Surface method to optimize the production and characterization of lipase from Penicillium verucosum in solid-state fermentation. J. Bioproc. and Biosys. Engineering 31: 119-125.

Kui, T., X. Xu, C. He and L. Li (2003). Lipasecatalysed modification of lard to produce human milk fat substitutes. Food Cap Chem. 80: 473-481.

Kulkarni, N. and R. V. Gadre (2002). Production and properties of an alkaline, thermophilic lipase from Pseudomonas fluorescens NS2W. J. Industrial Microbiol. Biotechnol., 28: 344-348.

Moon, S.H, and S.J, Parulekar (1991). Parametric study of protease production on batch and fed batch cultures of Bacillus firmus. J. Biotechnol. and Bioeng. 37:467-483

Nagayama, K., N. Yamasaki and M. Imai (2002). Fatty acid esterification catalysed by Candida rugosa lipase in lecithin microemulsion-based organogels. Biochem. Eng. J. 12: 231-236.

Nini, L.L., Sanda, L.C., Coumeau, E., Boitard, J.P., Dubes and H. Chahinian. (2001). Lipase catalysed hydrolysis of short-chain substrates in emulsion: a kinetic study. J. Biochem. Biophys. Acta. Molecular cell Biol.1534: 34-44.

Pallavi, P., Suresh, A., Srinivas, P. and RamReddy, P. (2010). Optimization lipase production by Staphylococcus sp. Lp12. African J. Biotechnol. 9(6): 882886.

Piao, J., T.Kobayashi, S. Adachi, K. Nakamish and R. Matsuno (2003). Synthesis of mono- and di-oleoyl erythritols through 
immobilized lipase- catalysed condensation of erythritol and oleic acid in acetone. Biochem. Eng. J. 14: 79-84.

Pogaku, P., A. Suresh, P. Srinivas and R.S. Ram (2010). Optimization of lipase production by Staphylococcus SP. LP12. African J. Biotechnol. 9 (6): 882-886

Rajesh, E.M, R. Arthe, R. Rajendran C. Balakumav, N. Pradeepa and S. Anitha. (2010). Investigation of lipase production by Trichoderma reese and Optimization of production parameters. Electronic $J$. Environ. Agric. and food chem. 9(7): 1177-1189.

Raku, T., M.Kitagana, H.Shimakana and Y. Tokiwa. (2003). Enzymatic synthesis of threolose esters having lipophilicity factors affecting their production. Canadian J. Microbiol. 39: 978-981.

Saxena, R.K, P.K Gosh, R. Gupta, W.S. Davidison, S. Brado and R. Gulati (1999). Microbial Lipase. Potential Biocatalysts for the future industry. J. Curr. Sci. 77(2). 77-80.

Sekhon, A, N. Dahiya and G.S. Hondal (2005). Production of extra cellular lipase by Bacillus megaterium AKG1 in submerged fermentation. Ind. J. Biotechnol. 5:179183

Shintre, M.S., R.S. Ghadge and S.B. Sawant (2002). Lipolase catalysed synthesis of benzyl esters of fatty acids. Biochem. Eng. J. 12: 131-141.

Sirisha, E., N. Rajasekar, and M. Lakshmi Narasu (2010). Isolation and Optimisation of Lipase producing bacteria from oil contaminated soil. Adv. Bio. Res. 4(5):
249-254.

Sommer, P., C. Bormann and F. Gotz (1997). Genetic and biochemical characterization of a new extracellular lipase from Streptomyces cinnamomeus. Appl. Environ. Microbiol. 63: 3553-3560.

Sugihara, A., Tani, T. and Tominaga, Y. (1991). Purification and characterization of a novel thermostable lipase from Bacillus sp. J Biochem.109:211-216.

Sumner, C, Krause, S, Sabot, A., Turner, K. and McNeil, C.J. (2001). Biosensor based on enzyme-catalysed degradation of thin polymer films. J. Biosens. Bioelectron. 16 (9-12): 709-714.

Szatajer, H. and I. Maliszeaska (1989). The effect of culture conditions on lipolytic productivity of Penicilliunm citrinum. Biotechnol. Letters 11:895-898

Szatajer, H. Maliszewka, I. and Wieczorek, J. (1988). Production of exogenous lipase by bacteria, fungi and actinomycetes. $J$. Enzyme and Microbial Technol. 10: 492497.

Vargas, G.D.L.P., H. Treichel, D. Oliveira, Beneti, S.C, D.M.G Freire and M.De luccio, (2008). Optimization of lipase production by Penicillium simplicissimum in Soy bean meal. J. Chem. Technol. and Biotechnol. 83:47-54

Wang, Y., K.C. Srivastava, G.J. Shen and H.Y. Wang (1995). Thermostable alkaline lipase from a newly isolated thermophilic Bacillus strain, A30-1(ATCC 53841). J. Ferment. Bio. Eng. 79: 433-438.

\section{How to cite this article:}

Nwachukwu, E., E.N. Ejike, B.U. Ejike, E.O. Onyeanula, R.O. Chikezie-Abba, N.A. Okorocha and Onukaogu, U.E. 2017. Characterization and Optimization of Lipase Production from Soil Microorganism (Serratia marcescens). Int.J.Curr.Microbiol.App.Sci. 6(12): 1215-1231. doi: https://doi.org/10.20546/ijcmas.2017.612.138 